\title{
POTENTIALITY OF UNDERUTILIZED CROP DIOSCOREA SPP.: A SOURCE OF NUTRACEUTICAL
}

\author{
F.N. Jahan ${ }^{1}$, M.A. Rahim ${ }^{1}$, S.M. Bokhtiar ${ }^{2}$ and A.K. Samanta ${ }^{2^{*}}$ \\ ${ }^{1}$ BAU-Germplasm Centre, Bangladesh Agricultural University, Mymensingh, Bangladesh \\ ${ }^{2}$ SAARC Agriculture Centre, BARC Complex, Farmgate, Dhaka, Bangladesh
}

\begin{abstract}
Good Health and Well-being is one of the important goals in the current decade of twenty first century. The people of current generation prefer the consumption of plant sourced bioactive molecules over the modern medicines because the former has no side effects and residue free. In order to mitigate the food requirement of growing global population during the previous century, the green revolution technologies focused on fewer crops leading to negligence of several important crops; popularly known as underutilized or neglected crops. In the list of underutilized crops, Dioscorea spp. occupies significant niche as it is rich in several phytochemicals and could be grown under multiple stress conditions faced by the modern agricultural practices. Besides, it has been known as prominent member under age old practices of "traditional health care system" to treat several malaises of human being during the early date of civilization. The tubers and bulbils of the Dioscorea spp. are rich in saponins, tannin, flavonoids, sterols, polyphenols, and glycosides in addition to its higher contents of basic essential nutrients such as protein, carbohydrates, vitamins, minerals etc. Further, its tubers are staple food for indigenous people of several Asian and African countries. Therefore, the Dioscorea spp. signifies as an important crop both to the next generation population as well as underprivileged class of people in the coming decade for good health wellbeing and food security.
\end{abstract}

Keywords: Dioscorea spp., Underutilized crop, Bulbil, Tubers, Phytochemicals, Good health

\section{INTRODUCTION}

Good Health and Well-being (Sustainable Development Goal 3) for every people is one of the major challenges for the entire world in the current decade of twenty first century. The particular goal needs to be addressed appropriately keeping in mind the scientific advancements achieved during the last few centuries vis a vis the current backdrop of changing lifestyle, consumer awareness, food safety and climate change

*Corresponding author: drashiskumarsamanta@gmail.com 
etc. In the course of human civilization, food was consumed in different forms to maintain health and well-being. Currently, the knowledge of health is being pursued for the improvement of food science and technology. It results into the emergence of the novel concept in the field of functional food science, popularly known as "Nutraceutical". The terminology "Nutraceutical" is amalgamation of two words: "Nutrition" and "Pharmaceutical". Even though, the particular scientific connotation is coined only during the fag end of the previous century by DeFelice L. Stephen in 1989 , but the philosophy to apply food as medicine was announced as early as 460 to 370 BC by the Greek physician cum philosopher, Hippocrates through his famous quote "Let food be thy medicine and medicine be thy food". In view of growing health care expenditure coupled with phobia against modern drugs and medicines, the current population is attracted towards the bioactive molecules of plant origin for health and well-being. A molecule is termed as nutraceutical if it effects beneficially one or more targeted physiological functions in the body along with prevention of disease (Dobbs and Bell, 2010).The term "Nutraceutical" as a promotional language was introduced in Japan nearly four decades ago. In fact, these bioactive compounds work on the principle of "Prevention is better than cure" to increase the quality of human life (Samanta et al., 2015; Roy et al., 2018). Albeit, the concept is newer in the field of functional food science, but the application of prebiotic or other nutraceuticals for healthcare is an age-old practice amongst the people of Asian countries particularly India and China (Samanta et al., 2011).

About 7000 plant species have been used in the crop husbandry practices out of the $2,50,000$ known plant species in the world. Surprisingly, $75 \%$ of world's food originates from merely twelve plants and five animal species (FAO, 1998). Further, if considers calorie intake, it is primarily derived from only three plants i.e. rice, wheat and maize (FAO, 2010). Evidently, such type agricultural practices are alarming not only for any country or region; but also, for the entire world because it leads to the development of the excessive homogeneity and oversimplification of both farming and food production system.

To meet the energy and protein requirement of growing global population, the modern agriculture has focused on a very limited number of crops and animals leading to driving the human diet and farmer's field to become increasingly alike around the world (Khoury et al., 2014). Such circumstance fails to give adequate attention to other food crops. The unattended crops are popularly known as "underutilized" or "neglected" or "forgotten" or "minor" crops. Nevertheless, few of these crops are perfectly fit in the category of "Nutraceutical", which are desired by the generation next population to counteract the lifestyle diseases, overcoming stress, avoiding modern medicines, boosting immunity etc. In the list of neglected crops, the Dioscorea spp. occupy significant niche because its root and bulbils are rich in several nutraceutical molecules possessing analgesic, anti-bacterial, anti-rheumatic, anti-oxidant, ant-diuretic, anti-tussive, and anthelmintic activities in addition to its ability to boost the function of liver, kidney and blood circulatory system, 
gastrointestinal tract (Sautour et al., 2007; Kuete et al., 2012; Mabhaudhi et al., 2017; Ou-yang et al., 2018). The yams are cultivated in most tropical countries especially in West Africa. Around 90\% of yam is produced in West Africa and it is the staple food in that region.

\section{Underutilized crops}

Unlike modern agricultural practices targeting to fewer crops, the people of ancient civilization have developed a remarkable diversity of foods to uphold the principles of biodiversity for fulfilling their daily requirements as well to counteract the weather vagaries (Padulosi et al., 2019). With powerful wisdom and inherited knowledge, people during the early date of civilization have domesticated thousands of plants and animals' species in spite of their dependence on food through "Gathering and Hunting" system (Heywood, 2013). Before the onset of industrial revolution, people of the particular region make best usages of the local resources to fulfil their daily requirements. The reliance and endurance on locally available ingredients resulted into the creation of vast collection of plant germplasm having therapeutic values in addition to basic nutritional qualities that are deeply rooted to local territories and culture (Padulosi et al., 2019). However, the modern agricultural practices narrowed down the diversity of crops leading to the development of risk on food security (Frison et al., 2011; Beddington et al., 2012). It results into underestimating the importance of biodiversity followed by neglecting the crops possessing significance from nutritional and therapeutic values. Nevertheless, the underutilized plant spreads across all food groups including the Dioscorea spp. (Ikiriza et al., 2019). Owing to their potentiality to grow and produce under marginal conditions (rainfed, slopping land, poor soil, low inputs, etc), the Dioscorea spp. offers opportunity for empowering and safeguarding food security of the most vulnerable community of the society (Padulosi et al., 2019).

\section{Dioscorea spp.}

Dioscorea spp. ('Kath aloo' in Assam, India, 'Pesta aloo' or 'Mete aloo'in Bangladesh, 'Guinea yam' in Africa), is one of the most important tuber crops in the world. It is an herbaceous plant with creeping and climbing vines and it comes under monocotyledonous Dioscoreaceae family (Burkill, 1960). With approximately 644 species, it is widely distributed in the tropical and temperate regions of Asia, Africa and America (Agbor-Egbe and Treche, 1995). It is one of the most important food crops since time immoral in several parts of the world because of its rich nutritional characteristics coupled with for traditional medicines as anticancer, antiinflammatory, antifungal, anti-rheumatism, hypoglycaemic, estrogenic, androgenic, contraceptives, gastropathy protective, antifungal, immunostimulant etc (Kumar et al., 2017). Recently, the global interest for promotion and conservation of Dioscorea spp. has increased several folds because of emerging challenges of the century i.e. ever-increasing population pressure, food security, climate change, fast depletion of 
natural resources, increasing input cost of modern agricultural practices, and finally the nutraceutical value of the particular plant (Shajeela et al., 2011).

According to the available reports, Dioscorea rotundata thought to be the first species that has been domesticated around 5000 BC in West Africa (Andres et al., 2017). The most economically important species under this genus is Dioscorea alata that is originated from Southeast Asia; possibly Myanmar and Thailand (Orkwor et al., 1998). Presently, the particular species of Dioscorea is spread across Malaysia, Indonesia, Philippines, Brazil, South America, Central America, Papua New Guinea, South Pacific Islands etc (Kumar et al., 2017). Air potato i.e. Dioscorea bulbifera is native to South Asia and is distributed among several countries namely Bangladesh, India, China, Cambodia, Indonesia, Java, Japan, Laos, Malaysia, Nepal, Pakistan, Sri Lanka, Thailand, Taiwan, Vietnam, Ghana, Gabon, Congo, Chad, Cameroon, Nigeria, Senegal, Sudan, Zimbabua, USA, Mexico, Cuba, Costa Rica, Jamaica, Nicaragua, Brazil, Ecuador, Peru, Venezuela, Australia etc. The other high yielding species is Dioscorea pentaphylla, a native of tropical Asia (Ayensu and Coursey, 1972). The particular species is found in India, Bangladesh, North America and other tropical Asian nations.

By virtue of its climbing nature, it could reach up to the height of $10 \mathrm{~m}$ or above depending upon the height of the supporting trees and shrubs (Fig.1). The twinning direction of the plant may be clockwise or anti-clockwise (Fig. 2). Rootstock are rhizomatous or tuberous (Lacaille-Dubois, 2002). Branching may be present or absent on the Stems. Leaves of the Dioscorea spp. are alternate or opposite and with or without pointed tips (Fig. 3). Major veins are aroused from the base of the leaves and become curved aligning with the leaf shape. The flowers of Dioscorea spp. are small with green or greenish grey or greenish yellow in colour (Fig. 4). These are unisexual (dioecious plants) and originate from leaf axils (Sautour et al., 2007). The number of flowers may reach as high as 15 to 20 or more on a single spike. The fruits of Dioscorea spp. is popularly known as bulbil (Fig.5) and very rich in nutraceuticals of immense significance (Kuete et al., 2012). It routinely originates from stem as a single or conjugate form with different shape (round, oval, irregular or elongate). Among all the member of Dioscoreaceae family, Dioscorea bulbifera is thought to be the most potential owing to its production of bulbils rich in phytochemicals active against piles, dysentery, syphilis, ulcers, cough, leprosy, diabetes, asthma and cancer (Ikiriza et al., 2019). The day length influences the formation of bulbils and shorter the length, bulbil production speeds up (Kumar et al., 2017). The root system of Dioscorea spp. is shallow, fibrous, and it may or may not be anchor type. It concentrates within the top layer of the soil (Onwueme, 1978). Tubers are of different shape, size and colour (Fig. 6). 

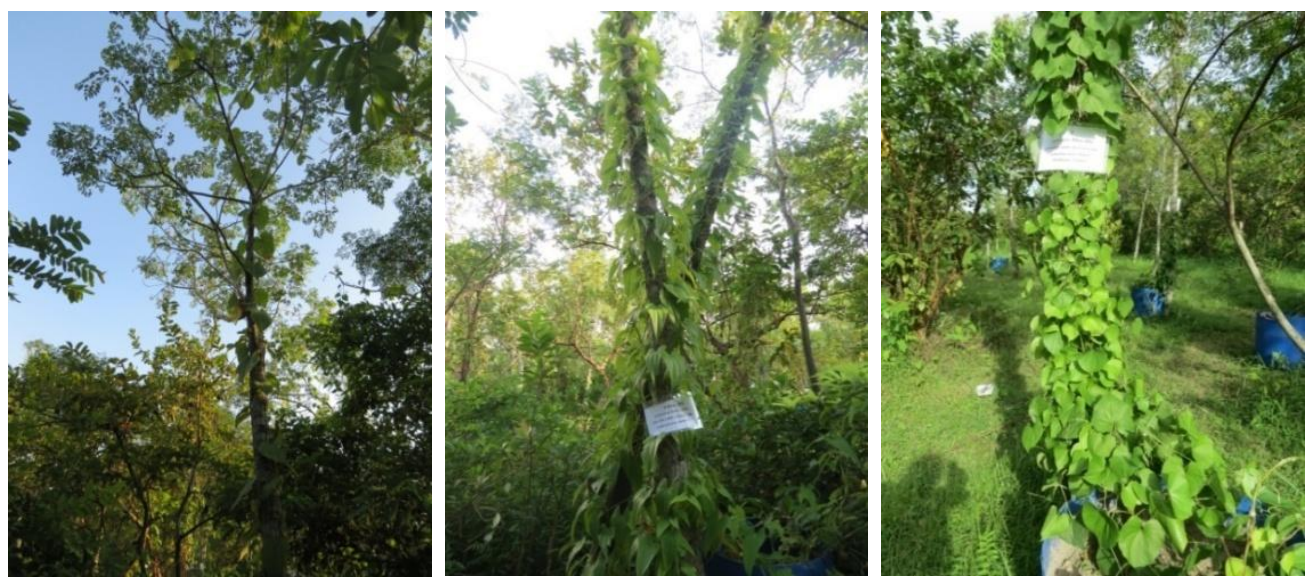

Figure 1. Climbing behaviour of Dioscorea spp.
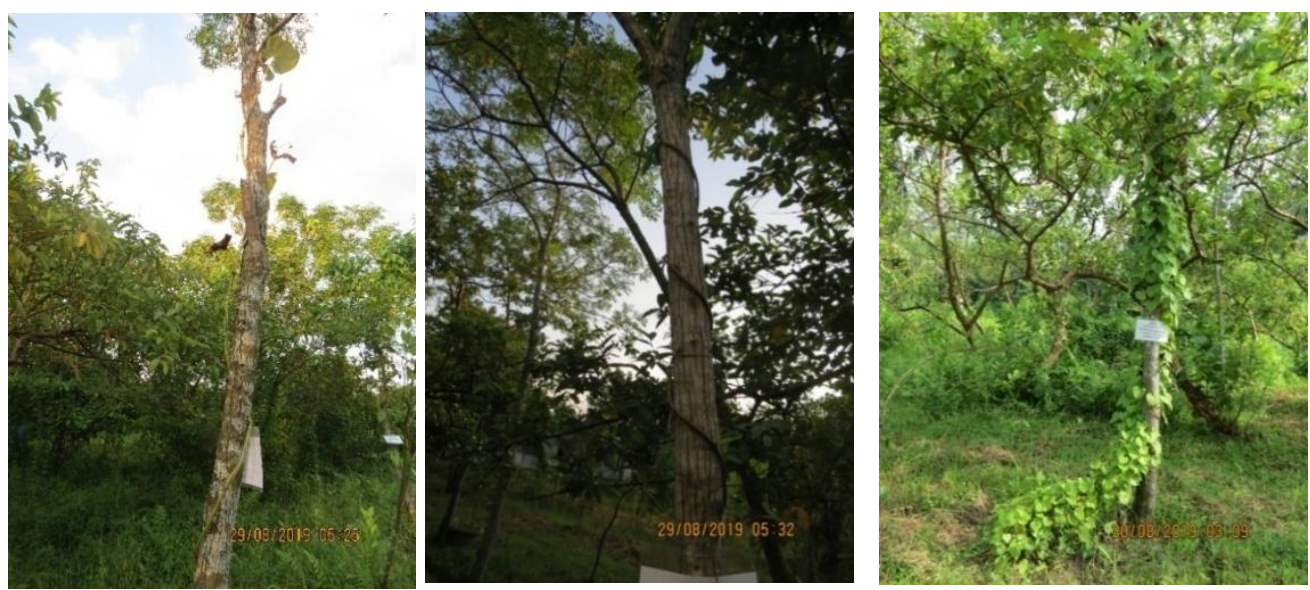

Figure 2. Twinning direction of Dioscorea spp.
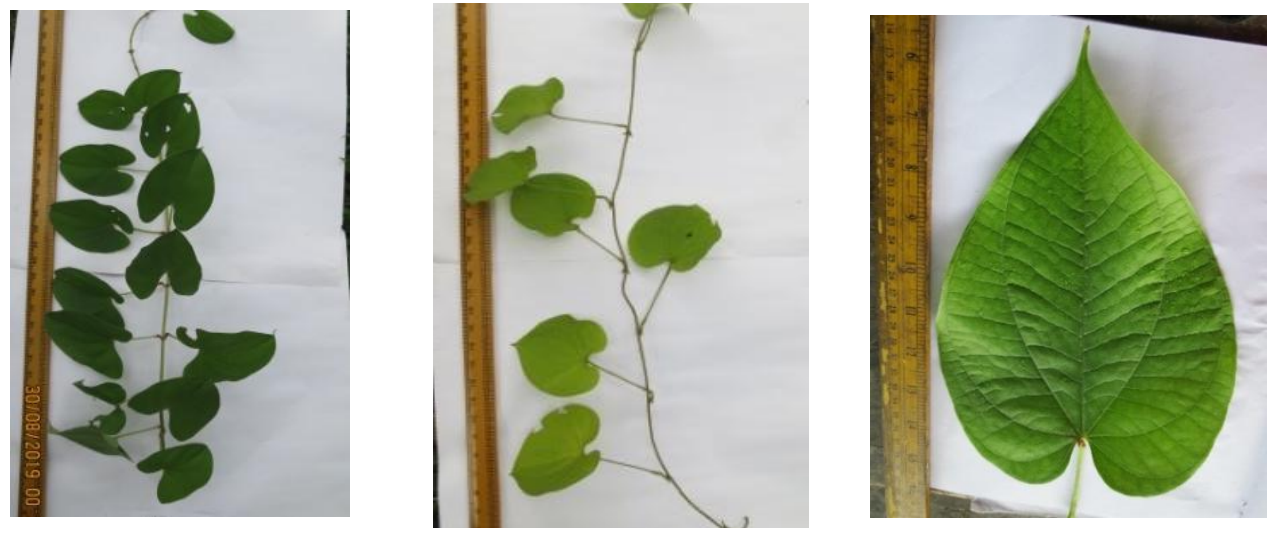

Figure 3. Leaves positioning of Dioscorea spp. 

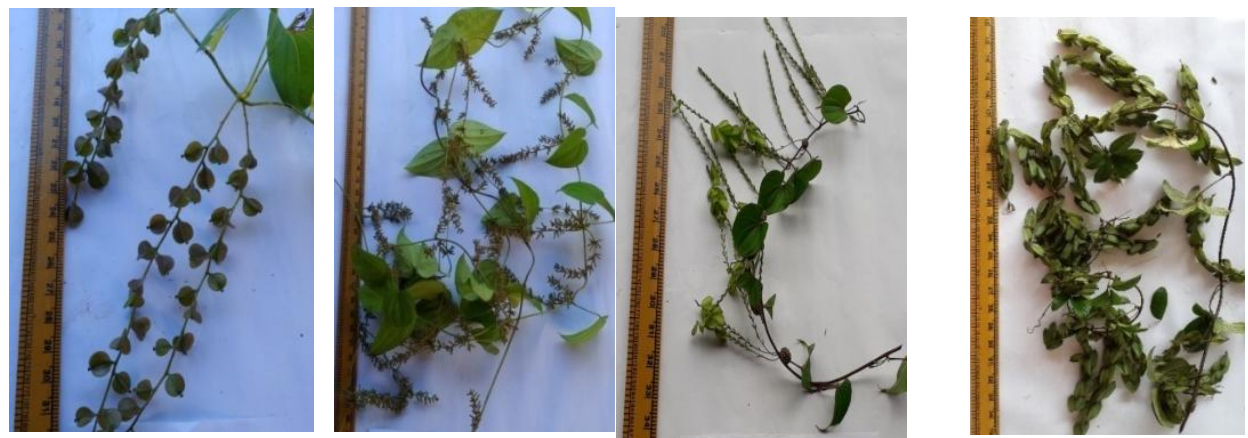

Figure 4. Flower of Dioscorea spp.

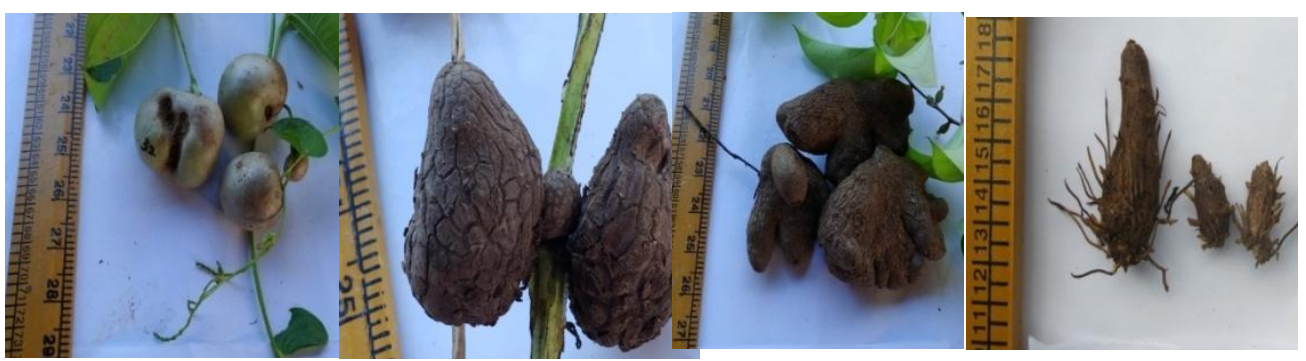

Figure 5. Bulbil of Dioscorea spp.
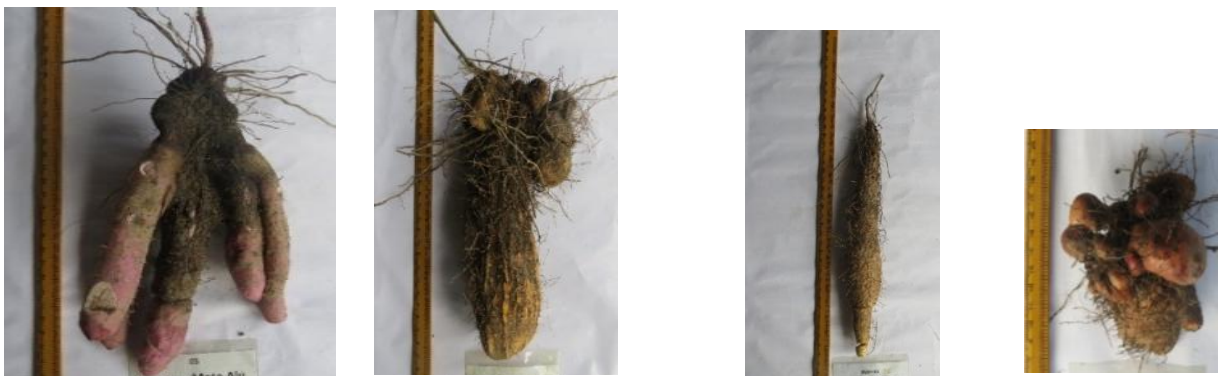

Figure 6. Tuber of Dioscorea spp.

\section{Classification of yam}

Out of the 644 species of Dioscorea (yam) genus, only a few of them are cultivated (Andres et al., 2017). It is broadly classified into four categories: (i) white yam, (ii) water yam, (iii) air potato, and (iv) bitter yam. Under white yam, important species are Dioscorea rotundata and Dioscorea cayenensis. The length of vines could reach up to $12 \mathrm{~m}$. The weight of each yam usually ranges between 2.5 to $5 \mathrm{~kg}$. The important species under water yam is Dioscorea alata and it is also known as "winged yam" or "purple yam". The height of this species could reach up to $10 \mathrm{~m}$ or 
more. Its tubers are large and purple in colour and often mistaken with taro (Colocasia esculenta) or purple sweet potato. Dioscorea bulbifera belongs to category of air potato that forms at the base of leaves. In case of air potato, bulbils are of much important than its tubers owing to its richness in terms of important phytochemicals having potentiality to act against several disease as part of traditional medicines. The term "air potato" seems to be originated from the size $(0.5-2 \mathrm{~kg})$ of the bulbils that equates with popular potato. It is hardly grown commercially. But under home garden practices, it starts bulbils production after 4 months and continues the production during the entire life of the vine (up to 2 years). Dioscorea dumetorum belongs to the class of bitter yam because of the presence of bitter principles which are toxic. Often, it is used to poison the animals (Andres et al., 2017).

\section{Composition of Dioscorea tubers and bulbils}

The consumption of Dioscorea tuber is common among the people of Bangladesh, India, Ethiopia, Uganda, Cameroon, and several other tropical and subtropical countries. In light of the global crisis on food availability in developing and least developed countries, the tubers of Dioscorea spp. are expected to play a vital role in mitigation of the above challenge as well as to address the SDG 3 i.e. Health and Well-being through its high value phytochemicals. The dry matter of the tuber ranges from 8 to 23\% (Megh et al., 2003; Abera, 2011; Shajeela et al., 2011). The compositional analysis (on dry matter basis) of tubers originated from different species of Dioscorea spp. revealed the presence of crude protein (6.2 to 13.4\%), crude fibre (0.4 to $7.6 \%)$, crude lipid (0.09 to $7.4 \%)$, total ash (3.3 to 6.3\%), nitrogen free extract (71 to $79 \%$ ), total carbohydrates (12 to 33\%) (Shajeela et al., 2011; Mulualem et al., 2018). Further, the tubers are rich in vitamins (niacin and ascorbic acid), minerals $(\mathrm{Ca}, \mathrm{P}, \mathrm{Mg}, \mathrm{Zn}, \mathrm{Mn}, \mathrm{Fe}$, and $\mathrm{Cu}$ ) and phenolic compounds (tannin, saponin).

The bulbils are produced by the Dioscorea bulbifera above the ground and popularly known as air potato as it looks like common potato grown under the soil. The important phytochemicals are phenols, tannins, alkaloids, flavonoids, saponins etc. The composition of bulbils is presented in Table 1. Evidently, the bulbils are rich in protein, carbohydrates, essential trace elements in addition to important phytochemicals (Celestine and David, 2015; Bolaniran et al., 2019). The quantity of phytochemicals present in the bulbils varies according to the place of harvest i.e. geographical locations, time of harvest, extraction conditions etc (Ikiriza et al., 2019). Along with beneficial phytochemicals, the bulbils are also reported to contain undesired plant secondary metabolites such as phytate, oxalate, hydrogen cyanide etc (Celestine and David, 2015). 
Table 1. Compositional analysis of bulbils

\begin{tabular}{lcc}
\hline \multirow{2}{*}{ Parameters } & \multicolumn{2}{c}{ Chemical composition of bulbils } \\
\cline { 2 - 3 } & Celestine and David (2015) & Bolaniran et al. (2019) \\
\hline Nutrients & & \\
Crude protein (\%) & $6.18 \pm 0.23$ & $15.48 \pm 0.02$ \\
Crude fat (\%) & $3.30 \pm 0.40$ & $0.49 \pm 0.03$ \\
Crude fibre (\%) & $7.97 \pm 0.75$ & $2.34 \pm 0.05$ \\
Total ash (\%) & $2.33 \pm 0.15$ & $1.26 \pm 0.03$ \\
Total carbohydrates (\%) & $76.68 \pm 0.78$ & $71.25 \pm 0.04$ \\
Energy value (KJ/100g) & $1530 \pm 26.33$ & Not reported \\
Phytochemicals & & $1.16 \pm 0.04$ \\
Phenols (mg g & & $2.50 \pm 0.01$ \\
Tannins (mg g & & $0.96 \pm 0.03$ \\
Alkaloids $\left(\mathrm{mg} \mathrm{g}^{-1}\right)$ & $+($ qualitative) & $1.56 \pm 0.03$ \\
Flavonoids (mg g & 0.37 & $3.57 \pm 0.02$ \\
Saponins $\left(\mathrm{mg} \mathrm{g} \mathrm{g}^{-1}\right)$ & $3.1 \pm 0.10$ & \\
\hline
\end{tabular}

\section{Therapeutic potential of Dioscorea spp.}

Before the introduction of modern science based therapeutic approach, the human healthcare system seems to be identical all over the world and popularly known as "Traditional Health Care System". In those days, the principle of traditional health system relies on two fundamentals: (i) application of natural product (extract or decoctions from leaves, roots, oils, fats, animal parts or insects) and (ii) appeal to spiritual forces (Neba, 2011). Even during the twenty first century, a large proportion (70\%) of world population still depends on the age-old practice i.e. traditional health care system because of its minimum side effects along with least cost (WHO, 2002; Ikiriza et al., 2019). Evidently, the different species of Dioscorea perfectly fit under the umbrella of traditional health care system because its richness of several phytochemicals which helps to overcome lifestyle diseases, faced by the current generation. Further, the presence of numerous phytochemicals makes the Dioscorea spp. as potential antioxidant, antibacterial, antifungal, anticarcinogenic, hypoglycaemic, immunostimulant (Son et al., 2007; Kumar et al., 2017). Therapeutic values of Dioscorea spp. against disease/ disorders are presented in Table 2. 
Table 2. Therapeutic application of Dioscorea spp.

\begin{tabular}{|c|c|c|c|}
\hline Name of species & $\begin{array}{c}\text { Plant } \\
\text { component }\end{array}$ & Purpose & References \\
\hline \multirow[t]{8}{*}{ Dioscorea bulbifera } & \multirow[t]{5}{*}{ Bulbils } & 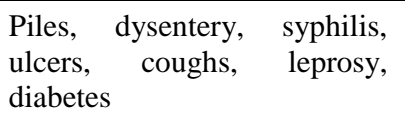 & Dutta (2015) \\
\hline & & Tuberculosis, sore throat & $\begin{array}{l}\text { Sharma and Bastskoti, } \\
\text { (2009) }\end{array}$ \\
\hline & & Contraceptives & Das et al. (2014) \\
\hline & & Sexual vigour enhancer & Subasini et al. (2013) \\
\hline & & Antibacterial drug & Kuete et al. (2012) \\
\hline & \multirow[t]{3}{*}{ Tubers } & Cough, asthma & Teron (2011) \\
\hline & & $\begin{array}{l}\text { Intestinal colic, } \begin{array}{r}\text { gastric } \\
\text { acidity, rheumatoid } \\
\text { arthritis, } \\
\text { dysmenorrhoea, } \\
\text { labour pain }\end{array}\end{array}$ & Kumar et al. (2017) \\
\hline & & $\begin{array}{l}\text { Ulcer, piles, syphilis, } \\
\text { dysentery }\end{array}$ & $\begin{array}{l}\text { Abhyankar } \\
\text { Upadhyay (2011) }\end{array}$ \\
\hline $\begin{array}{l}\text { Dioscorea } \\
\text { membranacea }\end{array}$ & Tubers & Breast cancer & Itharat et al. (2004) \\
\hline Dioscorea collettii & Tubers & $\begin{array}{l}\text { Cervical/ renal/ urinary } \\
\text { bladder carcinoma }\end{array}$ & Hu and Yao (2001) \\
\hline $\begin{array}{l}\text { Dioscorea } \\
\text { cayenensis }\end{array}$ & Tubers & Antifungal & Sautour et al. (2004) \\
\hline $\begin{array}{l}\text { Dioscorea } \\
\text { pentaphylla }\end{array}$ & Tubers & $\begin{array}{l}\text { Joint pain, immunostimulant, } \\
\text { stomach pain }\end{array}$ & Kumar et al. (2017) \\
\hline \multirow[t]{2}{*}{ Dioscorea alata } & \multirow[t]{2}{*}{ Tubers } & Piles, stomach worm & Kumar et al. (2017) \\
\hline & & Overcoming weakness & Kamble et al. (2010) \\
\hline $\begin{array}{l}\text { Dioscorea } \\
\text { dumetorum }\end{array}$ & Tubers & Jaundice & Edison et al. (2006) \\
\hline Dioscorea hirtiflora & Tubers & Gonorrhoea & $\begin{array}{l}\text { Sonibare and Abegunde } \\
\text { (2012) }\end{array}$ \\
\hline Dioscorea hispida & Tubers & $\begin{array}{l}\text { Vomiting, } \\
\text { purgatives }\end{array}$ & Dutta (2015) \\
\hline
\end{tabular}




\section{CONCLUSION}

The preference of next generation population has undergone a paradigm shift from modern therapeutic principles with synthetic compounds towards naturally occurring plant sourced bioactive molecules as these are safe, residue free, locally available and cheap. The entire global population is on the highways of information port that keeps the consumer abreast of the latest scientific developments relevant to healthcare and wellbeing. In the light of the above changing perspectives, phytochemicals have emerged as inevitable part of healthcare system to the consumers of all societal people because these biomolecules act in the principle of "Prevention is better than Cure" with minimal side effects and cheap. The underutilized crop "Dioscorea spp." possesses great potential to fulfil the expectations of generation next population through its valuable phytochemicals one hand and on the other side, it is capable to grow and produce even during climatic stress. Certainly, tubers of "Dioscorea spp." could find place as means of food security among most disadvantageous people of the society i.e. indigenous people. Usages of Dioscorea spp. either by generation next population (as source of phytochemicals) or by underprivileged people (as food or source of phytochemicals) is expected to push the human society nearer towards most important SDG3 i.e. "Good health and Well-being". Research investment, promotion, value chain creation on "Dioscorea spp." will not only turn the underutilized crop into valuable crop for the generation next population, but it will also step towards crop diversification for the benefit of the global agriculture.

\section{REFERENCES}

Abera, A.E. (2011). Proximate and mineral elements composition of the tissue and peel of Dioscorea bulbifera tuber. Pakistan Journal of Nutrition, 10: 543 - 551.

Abhyankar, R.K. and Upadhyay, R. (2011). Ethnomedicinal studies of tubers of Hoshangabad, M.P. Bulletin of Environment, Pharmacology and Life Sciences, 1: 57 59.

Agbor-Egbe, T. and Treche, S. (1995). Evaluation of chemical composition of Cameroonian germplasm. Journal of Food Composition Analysis, 8: 274 - 283.

Andres, C., Adeoluwa, O. and Bhullar, G.S. (2017). Yam (Dioscorea spp.). In: Encyclopaedia of Applied Plant Sciences. Vol. 3, Waltham, MA. Academic Press. Pp 435 - 441.

Ayensu, E.S. and Coursey, D.G. (1972). Guinea yams: the botany, ethnobotany, use and possible future of yams in West Africa. Economic Botany, 26: 301 - 318.

Beddington, J., Asaduzzaman, M., Clark, M., Fernandez, A., Guillou, M., Jahn, M., Mamo, T., Van Bo, N., Nobre, C.A., Scholes, R., Sharma, R. and Wakhungu, J. (2012). Achieving food security in the face of climate change: Final report from the Commission on Sustainable Agriculture and Climate Change, CGIAR Research Program on Climate Change. Agriculture and Food Security (CCAFS), Copenhagen, Demark. 
Bolaniran, T., Ogidi, C.O. and Akinyele, B.J. (2019). Nutritional value and safety of air potato Dioscorea bulbifera L. fermented with Pleurotusostreatus and Calocybeindica. Brazilian Journal of Biological Sciences, 6(13): 467 - 482.

Burkill, I.H. (1960). The organography and the evolution of Dioscoreaceae, the family of the yams. Journal of the Linnean Society of London, Botany, 56: 319 - 412.

Celestine, A.A. and David, O.I. (2015). Comparative nutritional and phytochemical evaluation of the aerial and underground tubers of air potato (Dioscorea bulbifera) available in Abakaliki, Ebonyi State, Nigeria. British Journal of Applied Science and Technology, 11(4): 1 -7.

Das, A., Chaudhuri, D., Ghate, N.B., Chatterjee, A. and Mandal, N. (2014). Phytochemical analysis, antioxidant and anticancer potenatial of leaf extracts from edible grater yeam, Dioscorea alata L., from North-East India. International Journal of Phytopharmacology, 5(2):109 - 119.

Dobbs, C.M. and Bell, L.N. (2010). Storage stability of Tagatose in buffer solutions of various compositions. Food Research International, 43(1): 383-386.

Dutta, B. (2015). Food and medicinal values of certain species of Dioscorea with special reference to Assam. Journal of Pharmacology and Phytochemistry, 3: 15 - 18.

FAO. (1998). The state of the world's plant genetic resources for food and agriculture. Food and Agriculture Organization of United Nations, Rome, Italy.

FAO. (2010). The second report on the state of the world's plant genetic resources for food and agriculture. Food and Agriculture Organization of United Nations, Rome, Italy.

Frison, E.A., Cherfas, J. and Hodgkin, T. (2011). Agricultural biodiversity is essential fora sustainable improvement in food and nutrition security. Sustainability, 3: 238 - 253.

Heywood, V.H. (2013). Overview of agricultural biodiversity and its contribution to nutrition and health. Pp. 35 - 67. In: J. Fanzo, D. Hunter, T. Borelli, and F. Mattei (eds.), Diversifying Food and Diets Using Agricultural Biodiversity to Improve Nutrition and Health. Earthscan, Routledge, 2 park square, Milton Park, Abindon, Oxon, United Kingdom.

Hu, K. and Yao, X.S. (2002) The cytotoxicity of methyl protoneodioscin (NSC-698791) against human cancer cell lines in vitro. Anticancer Research, 22(2A):1001 - 1005.

Ikizira, H., Ogwang, P.E., Peter, E.L., Hedmon, O., Tolo, C.U., Abubaker, M. and Abdalla, A.M. (2019). Dioscorea bulbifera, a highly threatened African medicinal plant, a review. Cogent Biology, 5: 1631561

Itharat, A., Houghton, P.J., Eno-Amooquaye, E., Burke, P.J., Sampson, J.H. and Raman, A. (2004). In vitro cytotoxic activity of Thai medicinal plants used traditionally to treat cancer. Journal of Ethnopharmacology, 90:33 - 38.

Kamble, S.Y., Patil, S.R., Sawant, P.S., Sawant, S., Pawar, S.G. and Singh, E.A. (2010). Studies on plants used in traditional medicines by Bhilla tribe of Maharashtra. Indian Journal of Traditional Knowledge, 9: 591 - 598.

Khoury, C.K., Bjorkman, A.D., Dempewolf, H., Ramirez-Villegas, J., Guarino, L., Jarvis, A., Rieseberg, L.H. and Struik, P.C. (2014). Increasing homogeneity in global food supplies and the implications for food security. Proceedings of National Academy of Sciences USA, 111: 4001 - 4006. 
Kuete, V., Teponno, R.B., Mbaveng, A.T., Tapondjou, L.A., Meyer, J.J.M., Barboni, L. and Lall, N. (2012). Antibacterial activities of the extracts, fractions and compounds from Dioscorea bulbifera. BMC Complementary and Alternative Medicine, 12: 228.

Kumar, S., Das, G., Shin, H.S. and Patra, J.K. (2017). Dioscorea spp. (a wild edible tuber): a study on its ethnopharmacological potential and traditional use by the local people of Simplipal biosphere reserve, India. Frontiers in Pharmacology, 8:52.

Lacaille-Dubois, M.A. (2002). A propos des Dioscorea (le “yam"). La Phytotherapie Europeenne, 7: $9-16$.

Mabhaudhi, T., Chimoyo, V.G.P., Chibarabada, T.P. and Modi, A.T. (2017). Developing a roadmap for improving neglected and underutilized crops: a case study of South Africa. Frontiers in Plant Science, 8:2143.

Megh, R.B., takanori, K. and Jun, K. (2003). Nutritional evaluation of wild yam (Dioscorea spp.) tubers of Nepal. Food Chemistry, 82: 619 - 623.

Mulualem, T., Mekbib, F., Hussein, S. and Gebre, E. (2018). Analysis of biochemical composition of yams (Dioscorea spp.) landraces from Southwest Ethiopia. Agrotechnology, 7:177.

Neba, N.E. (2011). Traditional health care system and challenges in developing ethnopharmacology in Africa: Example of Oku, Cameroon. Studies on EthnoMedicine, 5(2): 133-139.

Onwueme, I.C. (1978). The Tropical Root Crops: Yams, Cassava, Sweet Potato and Cocoyams. Chichester: John Wiley and Sons Ltd.

Orkwor, G.C., Asiedu, R. and Ekanayaka, I. J. (1998). Food Yams: Advances in Research. International Institute of Tropical Agriculture/NRCRI.

Ou-yang, S., Jiang, T. and Yi, T. (2018). Dioscorea nipponica Makino: a systematic review on its ethnobotany, phytochemical and pharmacological profiles. Chemistry Central Journal, 12: 57.

Padulosi, S., Cawthorn, D.M., Meldrum, G., Flore, R., Halloran, A. and Mattei, F. (2019). Leveraging neglected and underutilized plant, fungi, and animal species for more nutrition sensitive and sustainable food systems. Encyclopaedia of Food Security and sustainability, 3: 361-370.

Roy, S., Chikkerur, J., Roy, S.C., Dhali, A., Kolte, A.P., Sridhar, Manpal and Samanta, A.K. (2018). Tagatose as a potential nutraceutical: Production, properties, biological roles and applications. Journal of Food Science, 83 (11): 2699 - 2709.

Samanta, A.K., Jayapal, N., Jayaram, C., Roy, S., Kolte, A.P., Senani, S. and Sridhar, M. (2015). Xylooligosaccharides as prebiotics from agricultural by-products: Production and applications. Bioactive Carbohydrate and Dietary Fibre, 5(1): 62-71.

Samanta, A.K., Kolte, A.P., Senani, S., Sridhar, M. and Jayapal, N. (2011). Prebiotics in ancient Indian diets. Current Science, 101: 43 - 46.

Sautour, M., Mitaine-Offer, A.C., Miyamoto, T., Dongmo, A. and Lacaille-Dubois, M.A. (2004) Antifungal steroid saponins from Dioscorea cayenensis. Planta Medicines, 70(1): 90 - 92. 
Sautour, M., Mitaine-Offer, A.C. and Lacaille-Dubois, M.A. (2007). The Dioscorea genus: a review of bioactive steroid saponins. Journal of Natural Medicine, 61(2): 91-101.

Shajeela, P.S., Mohan, V.R., Jesudas, L.L. and Soris, P.T. (2011). Nutritional and antinutritional evaluation of wild yam (Dioscorea spp.). Tropical and Subtropical Agroecosystems, 14: 723 - 730.

Sharma, L. N and Bastakoti, R. (2009). Ethnobotany of Dioscorea L. with emphasis on food value in chepang communities in Dhading District, Central Nepal. Journal of Plant Science, 6: 12 - 17.

Son, I.S., Kim J.H., Sohn H.Y., Son, K.H., Kim J.S. and Kwon C.S. (2007). Antioxidative and hypolipidemic effects of diosgenin, a steroidal saponin of yam (Dioscorea spp.), on high-cholesterol fed rats. Bioscience, Biotechnology and Biochemistry, 71: 3063 3071.

Sonibare, N.A. and Abegunde, R.B. (2012). Ethnobotanical study of medicinal plants used by the Laniba village people in South Western Nigeria. African Journal of Pharmacology, 6: $1726-1732$.

Subasini, U., Thenmozhi, S., Sathyamurthy, D., Vetriselvan, S., Victor Rajamanickam, G. and Dubey,G. P. (2013). Pharmacognostic and phytochemical investigations of Dioscorea bulbifera L. International Journal of Pharmaceutical and Life Sciences, 4(5): 2693 2700.

WHO. (2002). WHO traditional medicine strategy 2002-2005. World Health Organisation Geneva, 1 - 74. 